\title{
Sugarcane pre-sprouted seedlings produced with beneficial bacteria and arbuscular mycorrhizal fungi
}

\author{
Lenise Rossetto $^{1}$ (D), Gabrielle Maria Fonseca Pierangeli (iD, Eiko Eurya Kuramae ${ }^{2,3}$ (D), Mauro \\ Alexandre Xavier $^{4}$ (D), Matheus Aparecido Pereira Cipriano ${ }^{1}$ (D), Adriana Parada Dias da Silveira ${ }^{1, \star}$ (D) \\ 1. Instituto Agronômico - Centro de Solos e Recursos Agroambientais, Campinas (SP), Brazil. \\ 2. Netherlands Institute of Ecology - Microbial Ecology Department - Wageningen, The Netherlands. \\ 3. Utrecht University - Institute of Environmental Biology - Ecology and Biodiversity Department - Utrecht, The Netherlands. \\ 4. Instituto Agronômico - Centro de Cana - Ribeirão Preto (SP), Brazil. \\ Received: Jun. 15, 2020 | Accepted: Dec. 7, 2020 \\ Section Editor: Gabriel Constantino Blain \\ *Corresponding author: adriana.silveira@sp.gov.br \\ How to cite: Rossetto, L., Pierangeli, G. M. F., Kuramae, E. E., Xavier, M. A., Cipriano, M. A. P. and Silveira, A. P. D. (2021). Sugarcane \\ pre-sprouted seedlings produced with beneficial bacteria and arbuscular mycorrhizal fungi. Bragantia, 80, e2721. https://doi. \\ org/10.1590/1678-4499.20200276
}

\begin{abstract}
The demand for the increased productivity of sugarcane crops has required changes in its production chain, such as the use of pre-sprouted seedlings (PSS) of sugarcane into the chain. In this system, the inoculation of beneficial microorganisms, such as plant growthpromoting bacteria (PGPB) and arbuscular mycorrhizal fungi (AMF), can improve seedling development. The objective was to evaluate the beneficial effect of PGPB and AMF inoculation on sugarcane PSS production system. Experiments were carried out in greenhouse using a commercial substrate with different levels of fertilization to evaluate the plant biomass and nutritional status. The bacteria strains are able to produce indole acetic acid and to amplify the nifH gene. The coinoculation of strains IAC-BeCa-095 with AMF (Glomus macrocarpum and Glomus etunicatum) improved the plant shoot biomass (25\%) on the fertilized substrate. The strains IAC-BeCa-088 (Burkholderia caribensis), IAC-RBca5 (Pseudomonas sp.) and IAC-RBca10 (Bacillus sp.) without AMF and fertilization improved the shoot biomass by up to $35 \%$. Coinoculation with strain IAC-BeCa-095 (Kosakonia radicincitans) and AMF improved the shoot and root biomass by up to 27 and $75 \%$, respectively, in the conventionally fertilized substrate, demonstrating a synergistic effect of these microorganism consortia. The use of beneficial microorganisms may be a viable practice in the production of PSS sugarcane. Moreover, this study is the first to demonstrate the synergistic effect of endophytic bacteria (K. radicincitans) or rhizobacteria (Bacillus sp.) with AMF and Pseudomonas sp. or B. caribensis, without AMF inoculum on the production of sugarcane PSS to improve plant growth and plant nutrition.
\end{abstract}

Key words: plant growth-promoting bacteria, rhizobacteria, endophytic bacteria, plant nutrition, arbuscular mycorrhiza.

\section{INTRODUCTION}

Beneficial microorganisms, such as plant growth-promoting bacteria (PGPB) and mycorrhizal fungi, have been explored worldwide to enhance plant performance (Bhardwaj et al. 2014; Venturi and Keel 2016). The plant microbiome harbors these beneficial microorganisms, which include different endophytic bacteria, such as Burkholderia, Herbaspirillum and Kosakonia, as well as those bacteria that inhabit the soil rhizosphere, recognized as plant growth-promoting rhizobacteria (PGPR), such as Azospirillum, Bacillus and Pseudomonas (Cipriano et al. 2016; Meena et al. 2017; Lata et al. 2018). The use of these bacteria is a growing and welcome eco-friendly technology in sustainable agriculture. The beneficial effect triggered by these bacteria is related to phosphate solubilization, biological nitrogen fixation (BNF), siderophore and hormone production (such as indole acetic acid - IAA) and biological control properties, such as hydrocyanic acid (HCN) production, which inhibit phytopathogen growth (Olanrewaju et al. 2017; Silveira et al. 2018). In addition to beneficial 
bacteria, among the fungal community, arbuscular mycorrhizal fungi (AMF) stablish a symbiotic association with the roots and favor plant development due to their capacity for the absorption and translocation of nutrients (Mohan et al. 2014; Tarraf et al. 2017). The large contribution of AMF to plant development is related to the absorption of ions, such as $\mathrm{H} 2 \mathrm{PO}$, $\mathrm{NH} 4$, copper $(\mathrm{Cu})$ and zinc $(\mathrm{Zn})$, which have slow diffusion and mobility in the soil (Guo et al. 2010). The benefit of mycorrhizal symbiosis represents an underexploited application to increase plant health and global food security (Rodriguez and Sanders 2015).

Plant growth-promoting bacteria and AMF have been used and marketed in the agricultural sector as inoculants for phytopathogen control and plant growth - promotion and are alternatives to pesticides and fertilizers in sustainable agriculture (Todeschini et al. 2018). In the case of endophytic and rhizosphere bacteria, several studies demonstrated a positive effect of these bacteria on plants of economic interest, including sugarcane (Cipriano et al. 2021; Schultz et al. 2017; Silveira et al. 2018). In the case of AMF, mycorrhizal symbiosis also improves plant growth and nutrient absorption in plants (Andrade et al. 2010; Tarraf et al. 2017) and enables phosphate fertilization to be reduced (Abdel-Fattah et al. 2014; Nunes et al. 2014).

Mycorrhizal fungi and PGPR play an important role in promoting plant growth through various mechanisms, and, when combined, these microorganisms can better benefit the host plant. For instance, the bacteria can enhance AMF germ tube elongation and hyphal branching, promoting symbiotic development of AMF and potato plants (Loján et al. 2017; Finkel et al. 2017). The combination of bacteria and AMF has other effects, such as reducing chemical fertilization and, in some cases, even improving tomato plant growth and fruit yield (Bona et al. 2018). The coinoculation of Pseudomonas monteilii and Glomus fasciculatum reduces the incidence of medicinal plant diseases, and also improve nitrogen $(\mathrm{N})$, phosphorus (P), and potassium (K) uptake (Singh et al. 2013). The synergistic effect of AMF and bacteria can be effective for sustainable agriculture, improving crop productivity (Nadeem et al. 2014).

Recently, studies on sugarcane have described the effect of new endophytic bacteria and rhizobacteria on plant growth due to improvements in photosynthesis and nitrogen metabolism (Rampazzo et al. 2018; Silveira et al. 2018). The search for bacterial inoculants and new techniques that can improve sugarcane production is ongoing because it is known that the endophytic community is diverse (Souza et al. 2016); however, this diversity can make it more difficult to establish exogenous microorganisms that benefit production. This information justifies the constant search for biotechnologies that mainly involve the use of bacteria and fungi that benefit plant development. In recent years, the sugarcane sector has adopted a new technology for seedling production, sugarcane pre-sprouted seedlings (PSS) (Landell et al. 2012).

Among the advantages of PSS system are quality and vigor control, greater homogeneity of seedlings and optimization of water and nutritional resources. Several studies have already described the beneficial effect of bacterial inoculants on sugarcane development (Kleingesinds et al. 2018; Marcos et al. 2016; Santos et al. 2018; Silveira et al. 2018), but the present study is the first to evaluate the benefit of plant-microorganism interactions with PGPB and AMF on sugarcane PSS focused in growth promoting and nutritional improvement. The evaluation of these beneficial microorganisms on sugarcane development can direct future studies on the inoculant recommendations for sugarcane PSS.

The hypothesis of this study is that the coinoculation of PGPB and AMF triggers a synergistic effect on seedlings, resulting in plants with a better nutritional status and greater biomass. In vitro tests were conducted to evaluate the effect of bacterial strains on plant growth-promoting traits and three experiments in greenhouse condition to investigate the hypothesis, using the endophytic and rhizobacterial strains combined or not with a mixture of two AMF species in substrates with different fertilization levels. Therefore, the aim was to a) characterize the bacterial strains regarding their plant-growth promoting traits and $b$ ) evaluate the effect of PGPB and AMF interaction on sugarcane PSS regarding plant growth and nutritional state.

\section{MATERIAL AND METHODS}

\section{Microorganisms}

The bacterial and arbuscular mycorrhizal fungal strains tested, which belong to the Beneficial Microorganisms Collection of Agronomic Institute, IAC, were: IAC-BeCa-088 (Burkholderia caribensis), IAC-BeCa-095 (Kosakonia radicincitans), 
IAC-RBca5 (Pseudomonas sp.), IAC-RBca10 (Bacillus sp.) and AMF strains, IAC-44 (Glomus etunicatum) and IAC-50 (Glomus macrocarpum).

\section{Plant growth-promoting bacteria traits - in vitro tests}

Hydrogen cyanide (HCN) production by the bacterial strains was evaluated according to Bakker and Schippers (1987); bacterial strains capacity to produce indole acetic acid (IAA) was also measured (Bric et al. 1991), and their ability to solubilize calcium phosphate was verified by the development of a halo surrounding the bacterial colonies grown on culture medium with inorganic phosphate (Katznelson and Bose 1959). The nifH gene analyses (related to BNF) were performed according to Ueda et al. (1995).

\section{Plant-microbe interaction on PSS of sugarcane in greenhouse experiments}

Inoculum preparation: the endophytic bacterial strains were grown on Dyg's liquid media (Döbereiner et al. 1995), and the rhizosphere bacterial strains were grown on PDA liquid media for $24 \mathrm{~h}$ at $28{ }^{\circ} \mathrm{C}$ in a shaker at $100 \mathrm{rpm}$. The cells were suspended in sterile $0.01 \mathrm{~mol} \cdot \mathrm{L}^{-1} \mathrm{MgSO}_{4} \cdot 7 \mathrm{H}_{2} \mathrm{O}$ solution after centrifugation (4000 rpm, $10 \mathrm{~min}$ ) and adjusted to a density of $10^{8}$ colony forming units (CFU) $\cdot \mathrm{mL}^{-1}$. The mycorrhizal inoculum was prepared based on a mixture of colonized root fragments, hyphae and spores of G. macrocarpum and G. etunicatum, referred to as AMF.

\section{Experimental design}

Three different experiments were conducted in a greenhouse at the Agronomic Institute (Campinas, Brazil 22 $54^{\circ} 20^{\prime \prime}$, $\left.47^{\circ} 05^{\prime} 34^{\prime \prime} \mathrm{W}\right)$. As there was no information about the effect of the bacterial strains on PSS, these seedlings were tested in three different scenarios, according to the fertilization management: experiment 1 - four strains tested on seedlings cultivated with partial recommended fertilization; experiment 2 - four strains tested on seedlings cultivated without the fertilization recommended; and experiment 3 - two strains tested on seedlings cultivated with recommended fertilization. All three experiments were carried out with a completely randomized design, which in experiments 1 and 2 were in a $5 \times 2$ factorial scheme (control and four bacterial strains - IAC-RBca5, IAC-RBca10, IAC-BeCa-088 and IAC-BeCa- $095 \times$ with or without AMF) and experiment 3 was in a $3 \times 2$ factorial scheme (control and two bacterial strains - IAC-RBca10 and IAC-BeCa-095 $\times$ with or without AMF). The control treatments for all three experiments were plants without bacteria and AMF inoculation.

\section{Experiments with plants and evaluation}

The sugarcane in all experiments was the cultivar IACSP 95-5000, which was supplied by the Sugarcane Center (IAC - Ribeirão Preto, Brazil). All the experiments were conducted with the same protocol used to prepare the sugarcane PSS (Landell et al. 2012). Basically, the one-bud stolks were treated with fungicides and germinated in trays filled with a commercial substrate (Tropstrato HA). The first mycorrhizal inoculation was performed at this phase: after preparing the trays with the substrate, $60 \mathrm{~mL}$ of soil was inoculated with the mycorrhizal inoculum (4400 spores/tray), and then the seedlings were sowed. Then, each seedling was inoculated with the bacterial suspension $(2 \mathrm{~mL})$. The control treatment was drenched with $0.01 \mathrm{~mol} \cdot \mathrm{L}^{-1} \mathrm{MgSO}_{4} \cdot 7 \mathrm{H}_{2} \mathrm{O}$ instead of the bacterial suspension. This procedure was used in all three experiments that were conducted in the greenhouse. The difference between the experiments was the substrate fertilization level, which is described below.

In experiment 1, partial fertilization was performed based on the fertilization procedure used in the Sugarcane Center to prepare PSS, which was in accordance with Landell et al. (2012) with some adaptations: after the budding sprouting period (15 days), the seedlings were transferred to tubes $(180 \mathrm{~mL})$ for seedling production, and the tubes 
were filled with the same substrate as already described, with AMF inoculum ( $15 \mathrm{~mL}, 1100$ spores). The plants were then treated again with the bacterial suspension $(2 \mathrm{~mL})$. In this phase, fertilization was performed at four different times. For the first fertilization, boron (B - 2\%), molybdenum $(\mathrm{Mo}-1 \%)$ and zinc $(\mathrm{Zn}-18 \%)$ were applied seven days after the seedlings were transplanted to the tubes. The second fertilization was performed 21 days after transplantation (DAT) with $\mathrm{CuSO}_{4} \cdot 5 \mathrm{H}_{2} \mathrm{O}(1.5 \mathrm{~g})$ and $\mathrm{MgCl}_{2} \cdot 6 \mathrm{H}_{2} \mathrm{O}(30 \mathrm{~g})$ diluted in $5 \mathrm{~L}$ of water. The third fertilization was performed 30 DAT with $\mathrm{Ca}\left(\mathrm{NO}_{3}\right)_{2}(75 \mathrm{~g})$ diluted in $5 \mathrm{~L}$ of water, and, at the fourth fertilization, the same nutrient was applied 40 DAT. Experiment 2 was performed the same way as experiment 1, but without fertilization after seedlings transplantation. Experiment 3 was conducted in the same way as described above, but with the complete fertilization that was recommended by Landell et al. (2012).

The experiments were performed using six replicates. All experiments were conducted over 60 days, and, thereafter, the plants were harvested for the evaluation of root and shoot growth (dry mass), AMF colonization (Giovannetti and Mosse 1980; Phillips and Hayman 1970), nutrient concentrations (Bataglia et al. 1983), nutrient content and nutrient use efficiency index (UEI) according to Siddiqi and Glass (1981). The data were submitted to analysis of variance and the Scott-Knott test at 5\%, using the statistical software Sisvar (Ferreira 2008).

\section{RESULTS}

The bacterial strains IAC-BeCa-088 and IAC-BeCa-095 amplified the nifH gene, and strain IAC-RBca5 was able to produce IAA (Table 1). None of the strains were able to produce $\mathrm{HCN}$, nor solubilize phosphate.

Table 1. Plant growth promoting substances production (+) or not (-) by endophytic and rhizospheric bacteria.

\begin{tabular}{|c|c|c|c|c|c|c|}
\hline Strains & Description & Classification & $\mathrm{HCN}^{\mathrm{a}}$ & $\mathrm{IAA}^{\mathrm{b}}$ & nifH ${ }^{c}$ & PS $^{d}$ \\
\hline IAC-RBca5 & Pseudomonas sp. & Rhizospheric & - & + & ND & - \\
\hline IAC-RBca10 & Bacillus sp. & Rhizospheric & - & - & ND & - \\
\hline IAC-BeCa-088 & Burkholderia caribensis & Endophytic & ND & - & + & - \\
\hline IAC-BeCa-095 & Kosakonia radicincitans & Endophytic & - & - & + & - \\
\hline
\end{tabular}

In experiment 1 (substrate with partial fertilization), there was interaction between bacterial strains and arbuscular mycorrhizal fungi mixture for shoot and root biomass. The inoculation of strains IAC-RBca5 (Pseudomonas sp.) and IAC-BeCa-088 (B. caribensis), without AMF inoculation, promoted increase on shoot growth compared to the other treatments (Fig. 1), increasing 26 and 36\%, respectively, in relation to the control. Coinoculation did not improve seedlings shoot growth, comparing to control plants (without PGPB inoculation). Coinoculation of the bacteria IAC-RBca10 (Bacillus sp.) or IAC-BeCa-095 and AMF mixture promoted an increase in shoot biomass (29 and 35\%, respectively) compared to the respective treatments without the AMF inoculation (Fig. 1). Bacterial inoculation, with or without AMF inoculation, did not cause a significant difference in root growth, but AMF inoculation caused a decrease of $34 \%$ in root biomass of control plants. Higher mycorrhizal colonization was observed in seedlings treated with strains IAC-RBca5, IAC-BeCa-088 and IAC-BeCa-095 (Fig. 2). It was observed that, even in the treatments without AMF inoculation, the roots were colonized by AMF.

Without AMF mixture inoculation, there was no significant difference between treatments in relation to plant shoot N, P and calcium (Ca) concentrations (Table 2). The plants treated with IAC-RBca5 (Pseudomonas sp.) and IACBeCa-088 (B. caribensis) showed higher shoot sulfur (S) and magnesium ( $\mathrm{Mg}$ ) concentrations, increasing 37 and $23 \%$ in relation to the control, respectively. All the bacterial strains increased in about $40 \%$ seedling shoot $\mathrm{K}$ concentration in relation to the control. Control plants showed significantly higher shoot $\mathrm{P}, \mathrm{K}, \mathrm{Mg}, \mathrm{S}$ and $\mathrm{Ca}$ concentrations in the treatments with AMF inoculation. 


\section{Experiment 1-partial fertilization}

Shoot

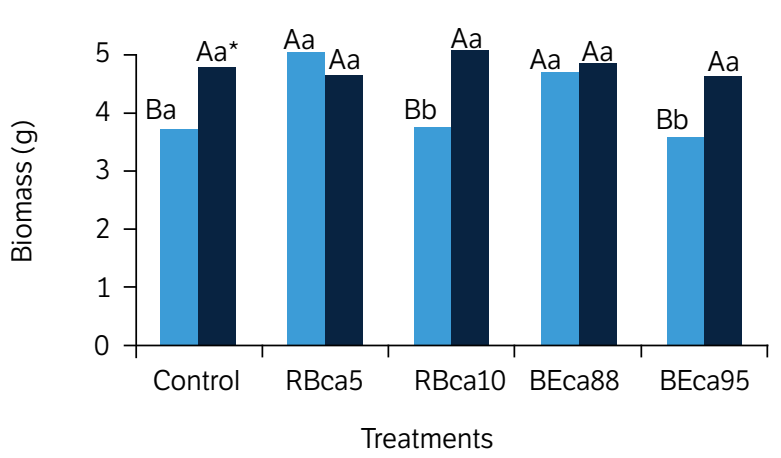

Root

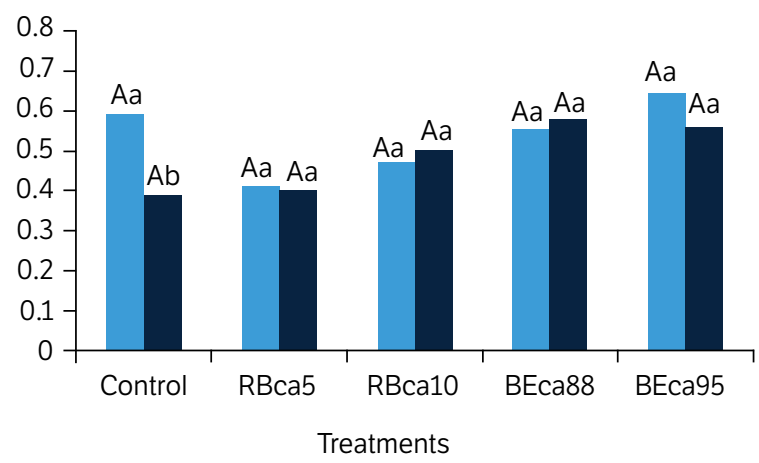

Experiment 2- without fertilization

Shoot

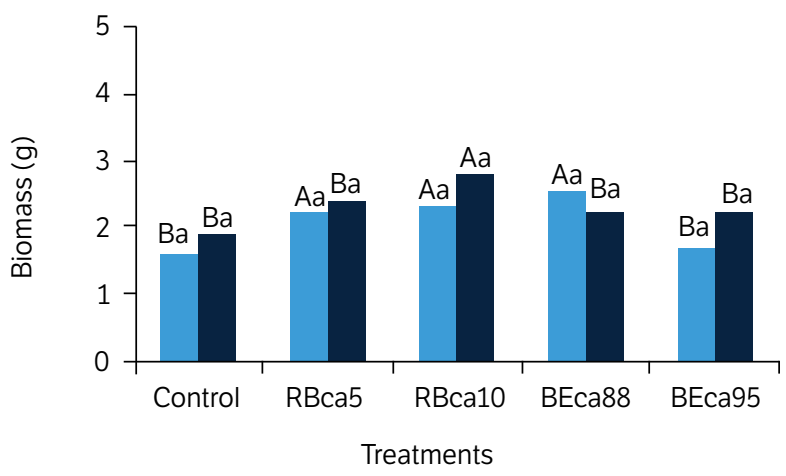

Root

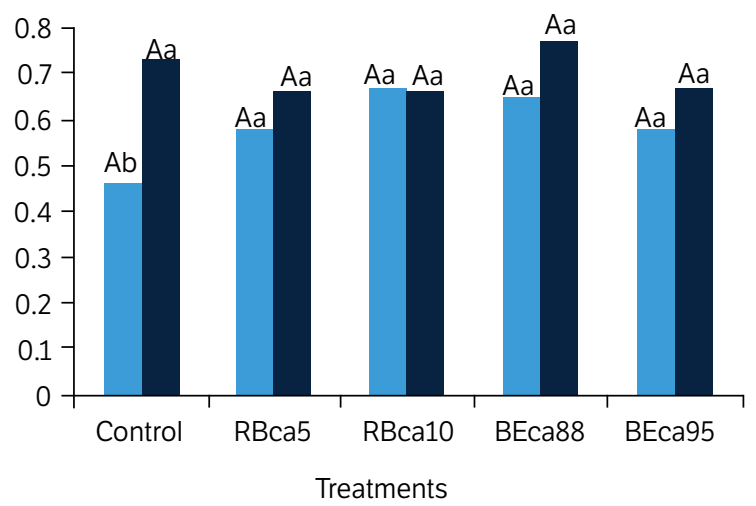

Experiment 3-recommended fertilization

Shoot

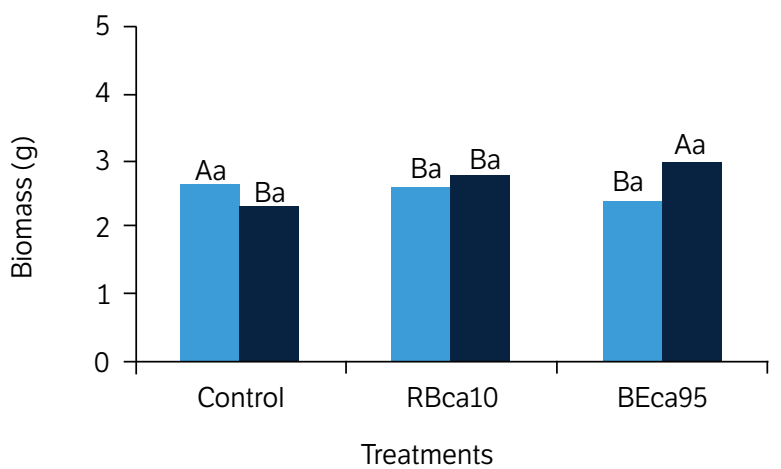

Root

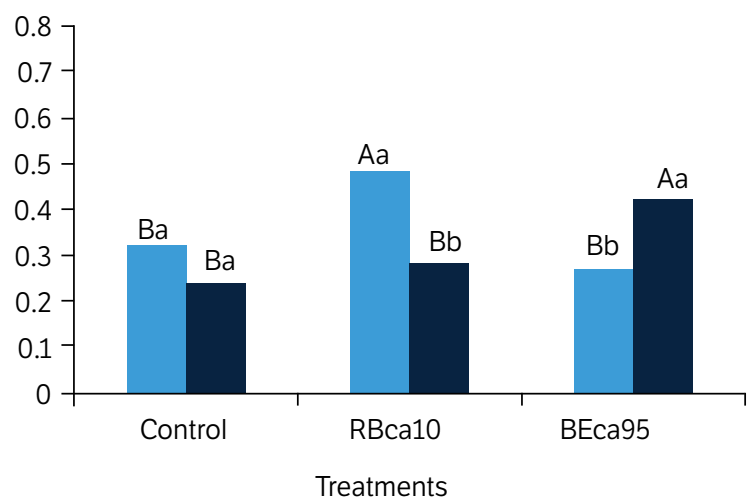

Without AMF inocula

With AMF inocula

Figure 1. Shoot and root dry mass ( $\mathrm{g}$ ) of sugarcane PSS treated with PGPB and AMF mixture. *Means with the same letter are not significantly different $(p<0.05)$ by the Scott-Knott's test. Capital letters compare bacterial treatments and lower case letters compare AMF inoculation. 
Experiment 1

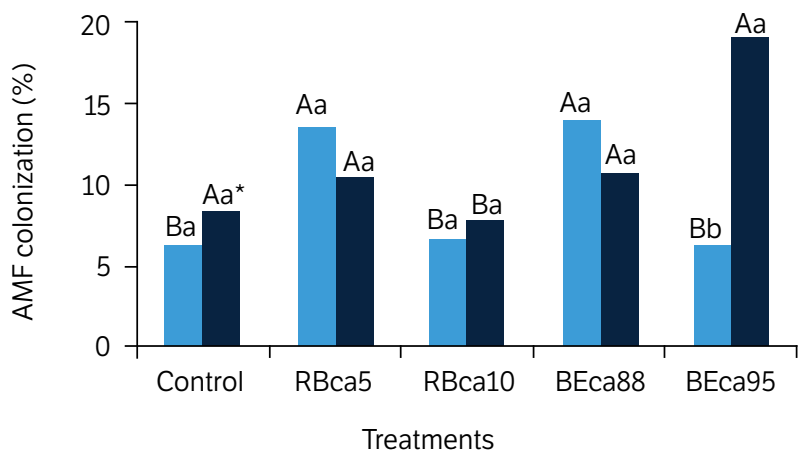

Experiment 2

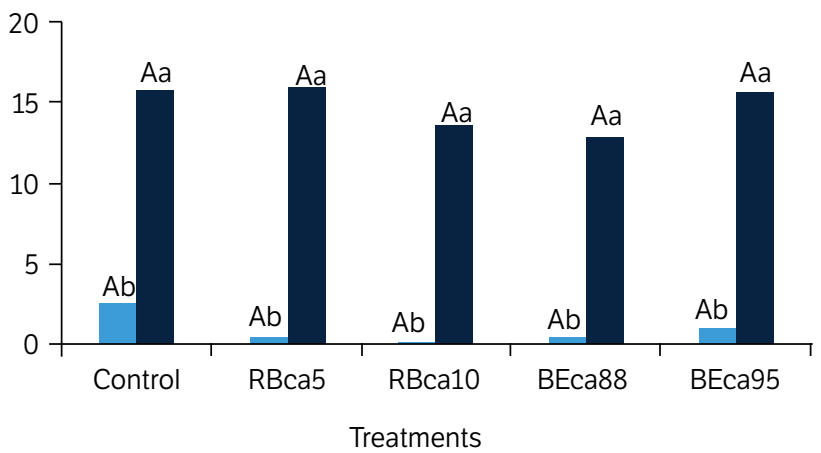

Without AMF inocula With AMF inocula

Figure 2. Mycorrhizal colonization of sugarcane PSS treated with PGPB. *Means with the same letter are not significantly different $(p<0.05)$ by the Scott-Knott's test. Capital letters compare bacterial treatments and lower case letters compare AMF inoculation.

Table 2. Shoot concentration $\left(\mathrm{g} \cdot \mathrm{kg}^{-1}\right)$, content ( $\mathrm{g} \cdot$ plant $\left.{ }^{-1}\right)$ and nutrient $\mathrm{UEl}\left(\mathrm{g}^{2} \cdot \mathrm{g}^{-1} \cdot\right.$ nutrient) of macronutrients in sugarcane seedlings inoculated with PGPB and mixture of AMF. (Experiment 1 - substrate with partial fertilization).

\begin{tabular}{|c|c|c|c|c|c|c|c|c|c|c|c|c|c|}
\hline \multirow{3}{*}{\multicolumn{2}{|c|}{$\begin{array}{c}\text { Macronutrients } \\
\text { Treatments }\end{array}$}} & \multirow{2}{*}{\multicolumn{2}{|c|}{$\begin{array}{c}\mathrm{N} \\
\mathrm{AMF}\end{array}$}} & \multirow{2}{*}{\multicolumn{2}{|c|}{$\begin{array}{c}P \\
A M F\end{array}$}} & \multirow{2}{*}{\multicolumn{2}{|c|}{$\begin{array}{c}\mathrm{K} \\
\mathrm{AMF}\end{array}$}} & \multirow{2}{*}{\multicolumn{2}{|c|}{$\begin{array}{c}\text { Mg } \\
\text { AMF }\end{array}$}} & \multirow{2}{*}{\multicolumn{2}{|c|}{$\begin{array}{c}\mathrm{S} \\
\mathrm{AMF}\end{array}$}} & \multirow{2}{*}{\multicolumn{2}{|c|}{$\begin{array}{c}\mathrm{Ca} \\
\mathrm{AMF}\end{array}$}} \\
\hline & & & & & & & & & & & & & \\
\hline & & Without & With & Without & With & Without & With & Without & With & Without & With & Without & With \\
\hline \multirow{5}{*}{ 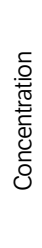 } & Control & $12.63 \mathrm{Ab}^{*}$ & 16.07Aa & 2.67Ab & $3.63 \mathrm{Aa}$ & $16.10 \mathrm{Bb}$ & $23.23 \mathrm{Aa}$ & $3.50 \mathrm{Ba}$ & 3.47Aa & $2.43 \mathrm{Bb}$ & $3.40 \mathrm{Aa}$ & $3.20 \mathrm{Ab}$ & 4.50Aa \\
\hline & IAC-RBca10 & $14.50 \mathrm{Aa}$ & $15.60 \mathrm{Aa}$ & $3.13 \mathrm{Aa}$ & $3.53 \mathrm{Aa}$ & 20.10Aa & 19.97Ba & 3.57Ba & $3.83 \mathrm{Aa}$ & 3.33Aa & $2.90 \mathrm{Ab}$ & 3.47Aa & $3.60 \mathrm{Ba}$ \\
\hline & IAC-RBca5 & 15.40Aa & $14.73 \mathrm{Aa}$ & 3.03Aa & $3.23 \mathrm{Aa}$ & $20.03 \mathrm{Aa}$ & $23.23 \mathrm{Aa}$ & $4.03 \mathrm{Aa}$ & 4.27Aa & 3.37Aa & 3.50Aa & 3.47Aa & 3.77Ba \\
\hline & IAC-BeCa-095 & 14.57Aa & $15.57 \mathrm{Aa}$ & 2.93Aa & $3.47 \mathrm{Aa}$ & $22.73 \mathrm{Aa}$ & $19.63 \mathrm{Ba}$ & $3.40 \mathrm{Ba}$ & 4.10Aa & $2.30 \mathrm{Bb}$ & 3.37Aa & $3.53 \mathrm{Ab}$ & $4.60 \mathrm{Aa}$ \\
\hline & IAC-BeCa-088 & 15.03Aa & $14.70 \mathrm{Aa}$ & $3.50 \mathrm{Aa}$ & 3.40Aa & 21.47Aa & $24.07 \mathrm{Aa}$ & $4.30 \mathrm{Aa}$ & 3.70Aa & 3.33Aa & 3.10Aa & 3.90Aa & 3.67Ba \\
\hline \multirow{5}{*}{ 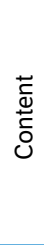 } & Control & 47.00Bb & 76.67Aa & 10.00Bb & 17.67Aa & $59.66 \mathrm{Cb}$ & 111.00Aa & $13.33 \mathrm{Bb}$ & 16.67Ba & $8.67 \mathrm{Cb}$ & 16.00Aa & $12.00 \mathrm{Bb}$ & $21.66 \mathrm{Aa}$ \\
\hline & IAC-RBca10 & $54.33 \mathrm{Bb}$ & 80.33Aa & $11.66 \mathrm{Bb}$ & 17.67Aa & 75.33Bb & $101.00 \mathrm{Ba}$ & 13.67Bb & 19.33Aa & 12.33Ba & 14.67Aa & $13.33 \mathrm{Bb}$ & 18.33Ba \\
\hline & IAC-RBca5 & 77.67Aa & $68.33 \mathrm{Bb}$ & 15.33Aa & 15.00Aa & 101.00Aa & 107.66Aa & 20.67Aa & 19.66Aa & 16.66Aa & 16.33Aa & 17.33Aa & $17.66 \mathrm{Ba}$ \\
\hline & IAC-BeCa-095 & $52.00 \mathrm{Bb}$ & $72.00 \mathrm{Ba}$ & $10.33 \mathrm{Bb}$ & $16.33 \mathrm{Aa}$ & 81.66Ba & $91.00 \mathrm{Ba}$ & $12.33 \mathrm{Bb}$ & 18.67Aa & $8.00 \mathrm{Cb}$ & 15.67Aa & $12.66 \mathrm{Bb}$ & 21.33Aa \\
\hline & IAC-BeCa-088 & 70.66Aa & 71.00Ba & 16.33Aa & 16.33Aa & $100.66 \mathrm{Ab}$ & 116.33Aa & 20.33Aa & $18.00 \mathrm{Bb}$ & 15.66Aa & 15.00Aa & 18.33Aa & $17.66 \mathrm{Ba}$ \\
\hline \multirow{5}{*}{ 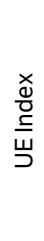 } & Control & $0.29 \mathrm{Ba}$ & $0.30 \mathrm{Ba}$ & $1.40 \mathrm{Ba}$ & $1.32 \mathrm{Aa}$ & $0.23 \mathrm{Aa}$ & $0.21 \mathrm{Ba}$ & 1.07Bb & $1.38 \mathrm{Aa}$ & $1.56 \mathrm{Aa}$ & $1.40 \mathrm{Ba}$ & 1.16Ba & 1.06Ba \\
\hline & IAC-RBca10 & $0.26 \mathrm{Cb}$ & $0.32 A a$ & 1.19Bb & 1.43Aa & $0.18 \mathrm{Bb}$ & $0.25 A a$ & $1.05 \mathrm{Bb}$ & $1.32 \mathrm{Aa}$ & $1.12 \mathrm{Bb}$ & 1.74Aa & $1.09 \mathrm{Bb}$ & 1.41Aa \\
\hline & IAC-RBca5 & $0.33 \mathrm{Aa}$ & $0.31 \mathrm{Aa}$ & 1.67Aa & $1.43 \mathrm{Ab}$ & $0.25 \mathrm{Aa}$ & $0.20 \mathrm{Bb}$ & 1.25Aa & $1.09 \mathrm{Bb}$ & $1.50 \mathrm{Aa}$ & 1.33Ba & 1.46Aa & $1.23 \mathrm{Ab}$ \\
\hline & IAC-BeCa-095 & $0.24 \mathrm{Cb}$ & $0.29 \mathrm{Ba}$ & 1.22Ba & $1.34 \mathrm{Aa}$ & $0.16 \mathrm{Bb}$ & $0.24 A a$ & $1.05 \mathrm{Ba}$ & 1.13Ba & $1.56 \mathrm{Aa}$ & $1.37 \mathrm{Ba}$ & $1.01 \mathrm{Ba}$ & 1.00Ba \\
\hline & IAC-BeCa-088 & $0.31 \mathrm{Aa}$ & $0.33 \mathrm{Aa}$ & $1.36 \mathrm{Ba}$ & $1.43 \mathrm{Aa}$ & $0.22 \mathrm{Aa}$ & $0.20 \mathrm{Ba}$ & $1.09 \mathrm{Bb}$ & $1.31 \mathrm{Aa}$ & $1.41 \mathrm{Aa}$ & $1.57 \mathrm{Aa}$ & $1.20 \mathrm{Ba}$ & $1.32 \mathrm{Aa}$ \\
\hline
\end{tabular}

*Means with the same letter are not significantly different $(p<0.05)$ by the Scott-Knott's test. Capital letters compare bacterial treatments and lower case letters compare AMF inoculation. Bold mean refers to the best result for each nutrient.

Plants treated with the strains IAC-RBca5 or IAC-BeCa- 088 showed significantly higher shoot macronutrients contents in the absence of AMF mixture inoculation (Table 2). Coinoculation of IAC-RBca5 (Pseudomonas sp.), IAC-RBca10 (Bacillus sp.) and IAC-BeCa-095 (K. radicincitans) and AMF mixture increased plant shoot Mg content, differing significantly from the control.

Plants treated with IAC-RBca5 showed the highest N, P, Mg and Ca UEI, differing significantly from the control plants (Table 2), without AMF mixture inoculation. Coinoculation with AMF and IAC-RBca10 promoted higher UEI of N, K, S and $\mathrm{Ca}$, differing significantly from the control plants. The same treatment improved the UEI of all plant macronutrients compared to plants only treated with the bacteria without AMF inoculation. 
Without AMF inoculation, shoot $\mathrm{Cu}$ and $\mathrm{Zn}$ concentrations did not differ among bacterial treatments, while shoot Fe concentration was significantly higher in control plants (without bacterium inoculation). The highest shoot Mn concentrations were observed in plants treated with IAC-BeCa-088 (B. caribensis) and IAC-RBca5 (Pseudomonas sp.), increasing in 105 and 74\%, respectively, in relation to the control. The inoculation of IAC-BeCa-088 also increased shoot B concentration by $34 \%$. The coinoculation of AMF and the strains IAC-BeCa- 088 and IAC-RBca5 significantly increased shoot iron (Fe) concentration. However, the inoculation of AMF mixture did not significantly alter shoot $\mathrm{B}$ and $\mathrm{Mn}$ concentrations. Coinoculation with the strains IAC-BeCa-088 and IAC-BeCa-095 (K. radicincitans) significantly decreased shoot $\mathrm{Cu}$ and Zn concentrations (Table 3).

Table 3. Shoot concentration $\left(\mathrm{g} \cdot \mathrm{kg}^{-1}\right)$, content $\left(\mathrm{g} \cdot \mathrm{plant}^{-1}\right)$ and nutrient $\mathrm{UEl}\left(\mathrm{g}^{2} \cdot \mathrm{g}^{-1} \cdot\right.$ nutrient $)$ of micronutrients in sugarcane seedlings inoculated with PGPB and mixture of AMF. (Experiment 1 ).

\begin{tabular}{|c|c|c|c|c|c|c|c|c|c|c|c|}
\hline & Micronutrients & & & & & & & & & & \\
\hline & & & & & & & & & & & \\
\hline & & Without & With & Without & With & Without & With & Without & With & Without & With \\
\hline & Control & $40.50 \mathrm{Aa}$ & $35.20 \mathrm{Bb}$ & $5.43 \mathrm{Ab}$ & 6.67Aa & $60.23 \mathrm{Bb}$ & 150.00Aa & $36.43 \mathrm{Ab}$ & $60.03 \mathrm{Aa}$ & $17.43 \mathrm{Bb}$ & 23.03Aa \\
\hline 들 & IAC-RBca10 & 37.70Ba & $38.73 \mathrm{Ba}$ & $5.43 \mathrm{Ab}$ & 6.77Aa & $85.00 \mathrm{Ba}$ & $122.13 \mathrm{Aa}$ & $45.80 \mathrm{Ab}$ & $66.57 \mathrm{Aa}$ & 14.17Ba & $19.20 \mathrm{Aa}$ \\
\hline 竞 & IAC-RBca5 & $37.33 \mathrm{Bb}$ & $42.80 \mathrm{Aa}$ & $5.00 \mathrm{Ab}$ & 6.47Aa & 105.00Aa & $114.73 \mathrm{Aa}$ & 42.37Aa & $57.00 \mathrm{Ba}$ & $16.37 \mathrm{Bb}$ & $22.33 \mathrm{Aa}$ \\
\hline రั & IAC-BeCa-095 & $37.30 \mathrm{Ba}$ & 37.07Ba & $5.50 \mathrm{Aa}$ & $5.27 \mathrm{Ba}$ & $72.23 \mathrm{Ba}$ & 113.47Aa & 47.77Aa & $49.13 \mathrm{Ba}$ & 11.13Ba & $22.10 \mathrm{Aa}$ \\
\hline & IAC-BeCa-088 & $36.77 \mathrm{Bb}$ & 42.97Aa & $5.30 \mathrm{Aa}$ & 4.57Ba & 123.97Aa & 119.37Aa & $54.60 \mathrm{Aa}$ & $40.27 \mathrm{Bb}$ & $23.43 \mathrm{Aa}$ & $18.47 \mathrm{Aa}$ \\
\hline & Control & $150.33 \mathrm{Cb}$ & $168.33 \mathrm{Ba}$ & $20.33 \mathrm{Bb}$ & $32.00 \mathrm{Aa}$ & $223.33 \mathrm{Cb}$ & $716.00 \mathrm{Aa}$ & $135.67 \mathrm{Db}$ & $286.66 \mathrm{Ba}$ & $64.67 \mathrm{Cb}$ & $110.33 \mathrm{Aa}$ \\
\hline & IAC-RBca10 & $141.33 \mathrm{Cb}$ & 195.33Aa & $20.00 \mathrm{Bb}$ & $34.00 \mathrm{Aa}$ & 318.33Bb & 617.00Ba & $171.66 \mathrm{Cb}$ & 336.67Aa & $53.00 \mathrm{Cb}$ & 97.00Ba \\
\hline$\stackrel{0}{\stackrel{2}{c}}$ & IAC-RBca5 & $188.00 \mathrm{Aa}$ & 198.33Aa & $25.33 \mathrm{Ab}$ & $29.66 \mathrm{Ba}$ & 529.33Aa & $532.00 \mathrm{Ca}$ & $213.67 \mathrm{Bb}$ & $264.33 \mathrm{Ba}$ & $82.33 \mathrm{Bb}$ & 103.66Aa \\
\hline & IAC-BeCa-095 & $133.66 \mathrm{Cb}$ & $171.00 \mathrm{Ba}$ & $19.66 \mathrm{Bb}$ & $24.00 \mathrm{Ca}$ & $259.00 \mathrm{Cb}$ & $526.00 \mathrm{Ca}$ & $171.00 \mathrm{Cb}$ & $227.33 \mathrm{Ca}$ & $40.00 \mathrm{Db}$ & $102.33 \mathrm{Aa}$ \\
\hline & IAC-BeCa-088 & $172.33 \mathrm{Bb}$ & $208.00 A a$ & $24.66 \mathrm{Aa}$ & $22.33 \mathrm{Ca}$ & 581.66Aa & 577.67Ba & $256.00 \mathrm{Aa}$ & 194.67Db & $110.00 \mathrm{Aa}$ & 89.67Bb \\
\hline & Control & $0.09 \mathrm{Bb}$ & $0.13 \mathrm{Aa}$ & $0.69 \mathrm{Ca}$ & $0.72 \mathrm{Ca}$ & $0.06 \mathrm{Aa}$ & $0.03 \mathrm{Bb}$ & $0.10 \mathrm{Ba}$ & $0.08 \mathrm{Cb}$ & $0.21 \mathrm{Ca}$ & $0.21 \mathrm{Ba}$ \\
\hline & IAC-RBca10 & $0.09 B b$ & $0.13 \mathrm{Aa}$ & $0.69 \mathrm{Ca}$ & $0.75 \mathrm{Ca}$ & 0.04Ba & $0.04 A a$ & $0.08 \mathrm{Ca}$ & 0.07Ca & $0.26 \mathrm{Ba}$ & $0.26 \mathrm{Aa}$ \\
\hline Ш & IAC-RBca5 & $0.13 \mathrm{Aa}$ & $0.11 \mathrm{Bb}$ & $1.00 \mathrm{Aa}$ & $0.72 \mathrm{Cb}$ & $0.05 \mathrm{Ba}$ & $0.04 \mathrm{Ab}$ & $0.12 A a$ & $0.08 \mathrm{Cb}$ & $0.31 \mathrm{Aa}$ & $0.21 \mathrm{Bb}$ \\
\hline & IAC-BeCa-095 & $0.09 B b$ & $0.12 \mathrm{Aa}$ & $0.65 \mathrm{Cb}$ & $0.88 \mathrm{Ba}$ & $0.05 \mathrm{Ba}$ & $0.04 \mathrm{Ab}$ & $0.07 \mathrm{Cb}$ & $0.09 B a$ & $0.32 \mathrm{Aa}$ & $0.21 \mathrm{Bb}$ \\
\hline & IAC-BeCa-088 & $0.13 \mathrm{Aa}$ & $0.11 \mathrm{Bb}$ & $0.89 \mathrm{Bb}$ & $1.06 \mathrm{Aa}$ & $0.03 \mathrm{Cb}$ & $0.04 \mathrm{Aa}$ & $0.08 \mathrm{Cb}$ & $0.12 A a$ & $0.20 \mathrm{Cb}$ & $0.26 \mathrm{Aa}$ \\
\hline
\end{tabular}

*Means with the same letter are not significantly different $(p<0.05)$ by the Scott-Knott's test. Capital letters compare bacterial treatments and lower case letters compare AMF inoculation. Bold mean refers to the best result for each nutrient.

The strains IAC-BeCa-088 and IAC-RBca5 promoted higher shoot contents of all micronutrients without AMF inoculation, differing significantly from the control (Table 3 ). Shoot $\mathrm{Zn}$ content was also significantly higher with the inoculation of all bacterial strains. The coinoculation of AMF and IAC-BeCa-088, IAC-RBca5 and IAC-RBca10 (Bacillus sp.) significantly increased shoot Fe content, and, with IAC-RBca10 strain, there was an increase in shoot $\mathrm{Zn}$ content. In general, AMF inoculation promoted higher shoot micronutrients accumulation.

Without AMF inoculation, plants treated with IAC-RBca5 and IAC-BeCa-088 showed higher Fe and Cu utilization efficiency index, differing significantly from control plants (Table 3). The UEI of B was higher in plants treated with IAC-RBca10, IAC-RBca5 and IAC-BeCa-095. Coinoculation of AMF and IAC-BeCa-088 and IAC-BeCa-095 promoted higher shoot $\mathrm{Cu}$ and $\mathrm{Zn} \mathrm{UEI}$, whereas for $\mathrm{Mn}$, all the coinoculated strains were more efficient than the control. Coinoculation with IAC-RBca10 and IAC-BeCa-088 caused significantly higher shoot B UEI.

In experiment 2 (substrate without fertilization), there was interaction between bacterial strains and arbuscular mycorrhizal fungi mixture for shoot biomass, but not for root biomass. In the treatments without AMF inoculation, the strains IAC-RBca5, IAC-RBca10 and IAC-BeCa-088 increased shoot biomass in 40, 44 and 60\%, respectively (Fig. 1). Coinoculation of IAC-RBca10 and AMF mixture improved shoot growth by up to $49 \%$. There were no significant differences between the 
treatments with and without AMF inoculation. The bacterial strains did not cause a significant increase in root biomass. The inoculation with AMF in the control plants improved root biomass up to 59\% (Fig. 1). The percentage of mycorrhizal colonization was significantly higher in plants inoculated with AMF mixture (Fig. 2).

In experiment 3 (substrate with recommended fertilization), there was interaction between bacterial strains and arbuscular mycorrhizal fungi mixture for shoot and root biomass. The coinoculation of IAC-BeCa-095 with AMF mixture improved shoot biomass in 30\% (Fig. 1). Arbuscular mycorrhizal fungi caused a significant decrease in shoot biomass (13\%) in the control treatments and an increase of $26 \%$ in biomass in the seedlings coinoculated with strain IAC-BeCa-095 compared to seedlings subjected to treatments without AMF. The seedlings inoculated with AMF and strain IAC-BeCa-095 had a greater root biomass than the control (75\%) and control without AMF (55\%), indicating a synergistic effect. In the treatment without AMF, strain IAC-RBca10 increased the root biomass (50\%); however, the treatments with AMF showed a significant decrease in root biomass that was up to $42 \%$. The percentage of mycorrhizal colonization of the seedlings ranged between 21.5 and $37.5 \%$, and there were no significant differences among the treatments.

Without AMF mixture inoculation, there was no significant difference among treatments in relation to plant shoot N, $\mathrm{P}$ and Mg concentrations (Table 4). The plants treated with IAC-BeCa-095 (K. radicincitans) showed higher shoot K concentration and lower Ca concentration. With AMF mixture inoculation, there was no significant difference among treatments in relation to plant shoot N, Mg and S concentrations. Coinoculation of IAC-BEca-095 and AMF mixture increased plant shoot K and Ca concentrations, and both isolates (IAC-BEca-095 and IAC-RBca10) increased shoot P concentration in relation to control plants (without bacterial inoculation). Coinoculation of IAC-BEca-095 and AMF mixture increased plant shoot P and Ca concentrations, comparing to the treatment without AMF inoculation.

Plant shoot N, P, K and S contents did not differ among treatments in the absence of AMF mixture inoculation, but shoot $\mathrm{Mg}$ and Ca contents decreased in plants treated with IAC-BEca-095. Coinoculation of AMF mixture and IAC-BEca-095 or IAC-RBca10 (Bacillus sp) promoted higher shoot N, P, K and Mg. Coinoculation with IAC-BEca-095 increased shoot S and Ca contents. This treatment also increased significantly all shoot macronutrients contents compared to the treatments without AMF mixture inoculation (Table 4). Coinoculation of AMF and IAC-BEca-095 or IAC-RBca10 promoted higher UEI of N, S and Ca. Without AMF mixture inoculation, the UEI of all macronutrients did not differ significantly among treatments (Table 4).

Without AMF mixture inoculation, there was no significant difference among treatments in relation to plant shoot $\mathrm{Cu}$ and B concentrations (Table 5). The plants treated with IAC-BEca-095 showed lower shoot Mn, Fe and Zn concentrations. The inoculation of IAC-RBca-10 increased shoot Fe concentration in 54\%, comparing to control plants. With AMF mixture inoculation, there was no significant difference among treatments in relation to shoot $\mathrm{Fe}$ and $\mathrm{Zn}$ concentration. Coinoculation with IAC-BEca-095 or IAC-RBca10 increased significantly shoot B concentration, in 40 and 20\% respectively, and shoot Mn. Coinoculation with IAC-BEca-095 increased seedlings shoot $\mathrm{Cu}, \mathrm{Mn}$ and $\mathrm{Zn}$ concentrations, comparing to without AMF inoculation (Table 5).

Plant shoot $\mathrm{Cu}$ and $\mathrm{B}$ contents did not differ among treatments without AMF mixture inoculation (Table 5). Plants treated with IAC-BEca-095 showed significant decrease in shoot $\mathrm{Mn}, \mathrm{Zn}$ and Fe contents. Shoot Fe content increased in about $80 \%$ in plants treated with IAC-RBca10 in relation to control plants. Coinoculation of AMF mixture and IAC-BEca-095 or IAC$\mathrm{RBca} 10$ increased shoot $\mathrm{Cu}, \mathrm{Mn}, \mathrm{Zn}$ and $\mathrm{B}$. Inoculation of $\mathrm{AMF}$ increased significantly shoot $\mathrm{Mn}, \mathrm{Zn}, \mathrm{Cu}$ and $\mathrm{B}$ contents in plants treated with IAC-BEca-095, compared to the respective treatment without the AMF inoculation (Table 5). Coinoculation with IAC-BEca-095 and AMF caused significant increase in shoot Zn UEI.

\section{DISCUSSION}

The experiments were conducted in a similar way to the current method of sugarcane PSS production and showed different responses regarding biomass improvement, colonization and shoot plant nutrient status. 
In experiment 1, the bacterial strains IAC-RBca5 (Pseudomonas sp.) and IAC-BeCa-088 (B. caribensis) improved shoot growth in the treatments without AMF (Fig. 1). The beneficial effect of PGPB strains, such as Pseudomonas, has already been observed in sugarcane seedlings (González et al. 2015). Surprisingly, the seedlings without AMF but inoculated with strains IAC-RBca5 and IAC-BeCa-088 had higher mycorrhizal colonization than the control treatment without AMF (Fig. 2). Pseudomonas species are considered as mycorrhizal helper bacterium, which could be useful in organic agriculture due to their ability to improve the percentage of AMF colonization and spore number retrieved from soil (Singh et al. 2013). Moreover, the AMF can increase root branching due to different mechanisms, such as production and action of AMF exudates, and also increase of mineral nutrition and modulation of hormone balance (Fusconi 2014).

In the present experiment, it was expected that the type of organic substrate, which was composed of pine bark, would not have AMF propagules, since no soil was added. According to Tahat and Sijam (2012), mycorrhizal fungi colonization occurs only in the presence of exudates released by host root plant that can favor the establishment of the symbiosis. The AMF colonization observed in the present experiment may have occurred due to the presence of native AMF propagules in the substrate and recruited by the plant, since a sterilized substrate was not used. The coinoculation of strain IAC-BeCa-095 ( $K$. radicincitans) and AMF caused higher seedling mycorrhizal colonization than the other treatments, but did not confer other benefits, such as a biomass increase and higher nutrient uptake. This may have happened because the level of mycorrhizal colonization was not related to the growth of the plant in this case. The low percentage of root colonization by AMF may be due to the fungicide treatments performed during sugarcane seedling production (Reis et al. 1994). This is an important observation because the use of fungicides is part of the management of sugarcane PSS production. Despite the factors of fungicides treatments and partial fertilization that were imposed in Experiment 1, strains IAC-RBca5 and IAC-BeCa-088 had a positive effect on the sugarcane PSS by improving the shoot biomass.

Regarding plant nutritional status, all seedlings subjected to treatments with PGPB strains but without AMF had higher shoot $\mathrm{K}$ concentration than the control seedlings (Table 2 ). The ability to mobilize nutrients, such as $\mathrm{K}$, that are assimilated and used by plants is one of the most effective benefits of PGPB (Badr 2006; Cipriano et. al 2021)

The results of experiment 3 evidenced that seedlings inoculated with strain IAC-BeCa-095 (K. radicincitans) and AMF had a greater root biomass than the control treatment (Fig. 1) and also in concentrations of macro and micronutrients (Table 4 and 5). The improvement in root growth is an important indicator of the benefits of microorganism inoculation because it can trigger other beneficial effects, such as nutrient and water absorption (González et al. 2015; Silveira et al. 2016). The increase in root biomass production could be due to the availability of nutrients from the action of microorganisms that fix $\mathrm{N}$, organic matter mineralization, phosphate solubilization and siderophore production (Jacoby et al. 2017). According to Wu et al. (2005), the growth improvement of maize plants inoculated with Bacillus species and AMF was due to the greater ability of plants to assimilate N, P and K. Based on this information and the data of this study, it was hypothesized that strains IAC-RBca10 and IAC-BeCa-088, when inoculated with AMF, trigger an increase in biomass root production and result in an increase in macronutrients (N, P, K and Mg, Table 2) and micronutrients (Mn, $\mathrm{Zn}$ and B, Table 3) content. The beneficial effect triggered by Bacillus on sugarcane PSS growth and nutrition has already been reported (Santos et al. 2018). The inoculation of five diazotrophic bacteria (Gluconacetobacter, Herbaspirillum seopedicae, H. rubisubalbicans, Paraburkholderia and Nitrospirillum) also improved sugarcane biomass and N, P and $\mathrm{K}$ accumulation, especially under low $\mathrm{N}$ conditions (Santos et al. 2020). As far as it is known, this is the first data showing that AMF combined with Pseudomonas sp. (IAC-RBca5) or K. radicincitans (IAC-BeCa-095) improved biomass production and nutrient use of sugarcane PSS. Other combinations of PGPB, such as Azotobacter and Paenibacillus, with AMF are also able to improve Poaceae plants growth, such vetiver ecotypes (Bhromsiri and Bhromsiri 2010). Coinoculation with bacteria and fungi is a good way to promote plant growth because together these microorganisms can modify the plant root system and manipulate the hormonal pathways, such as the production of cytokinins and auxins that promote root elongation (Cormier et al. 2016). 
Table 4. Shoot concentration $\left(\mathrm{g} \cdot \mathrm{kg}^{-1}\right)$, content $\left(\mathrm{g} \cdot \mathrm{plant}^{-1}\right)$ and nutrient $\mathrm{UEI}\left(\mathrm{g}^{2} \cdot \mathrm{g}^{-1} \cdot\right.$ nutrient $)$ of macronutrients in sugarcane seedlings inoculated with PGPB and mixture of AMF. (Experiment 3).

\begin{tabular}{|c|c|c|c|c|c|c|c|c|c|c|c|c|c|}
\hline & Macronutrients & 1 & & r & & & & $N$ & & $s$ & & & \\
\hline & & Al & & Al & & & & Al & & Al & & & \\
\hline & & Without & With & Without & With & Without & With & Without & With & Without & With & Without & With \\
\hline 등 & Control & 15.77Aa & 16.33Aa & $3.80 \mathrm{Aa}$ & $3.70 \mathrm{Ba}$ & $27.23 \mathrm{Ba}$ & $25.80 \mathrm{Ba}$ & $3.53 \mathrm{Aa}$ & $3.40 \mathrm{Aa}$ & $4.20 \mathrm{Aa}$ & $3.83 \mathrm{Aa}$ & $6.57 \mathrm{Aa}$ & 5.87Bb \\
\hline$\frac{5}{8}$ & IAC-RBca10 & $16.47 \mathrm{Aa}$ & 16.10Aa & 3.97Aa & 4.17Aa & $28.90 \mathrm{Ba}$ & $28.73 \mathrm{Ba}$ & 3.57Aa & 3.70Aa & 3.87Ba & $3.73 \mathrm{Aa}$ & $5.37 \mathrm{Ba}$ & $4.93 \mathrm{Ca}$ \\
\hline రิ & IAC-BeCa-095 & $16.70 \mathrm{Aa}$ & $16.83 \mathrm{Aa}$ & 3.67Ab & 4.17Aa & 31.57Aa & $31.83 \mathrm{Aa}$ & $3.40 \mathrm{Aa}$ & 3.73Aa & $4.30 \mathrm{Aa}$ & $4.30 \mathrm{Aa}$ & $5.40 \mathrm{Bb}$ & $6.57 \mathrm{Aa}$ \\
\hline & Control & $41.66 \mathrm{Aa}$ & $38.67 \mathrm{Ca}$ & $10.33 \mathrm{Aa}$ & $8.66 \mathrm{Ba}$ & $72.00 \mathrm{Aa}$ & $61.00 \mathrm{Cb}$ & $9.33 \mathrm{Aa}$ & $8.33 \mathrm{Ba}$ & $11.00 \mathrm{Aa}$ & $9.00 \mathrm{Ba}$ & $17.33 \mathrm{Aa}$ & $13.66 \mathrm{Bb}$ \\
\hline$\stackrel{\overline{ \pm}}{ \pm}$ & IAC-RBca10 & 43.00Aa & 44.33Ba & 10.33Aa & $11.66 \mathrm{Aa}$ & $74.66 \mathrm{Aa}$ & $79.33 B a$ & $9.00 \mathrm{Ab}$ & $10.33 \mathrm{Aa}$ & $10.00 \mathrm{Aa}$ & $10.00 \mathrm{Ba}$ & $14.00 \mathrm{Ba}$ & $13.66 \mathrm{Ba}$ \\
\hline & IAC-BeCa-095 & $39.66 \mathrm{Ab}$ & 50.33Aa & $9.00 \mathrm{Ab}$ & $12.33 \mathrm{Aa}$ & $74.66 \mathrm{Ab}$ & $94.66 \mathrm{Aa}$ & 8.00Bb & 11.33Aa & $10.00 \mathrm{Ab}$ & $13.00 \mathrm{Aa}$ & $12.66 \mathrm{Bb}$ & 19.33Aa \\
\hline & Control & $0.17 \mathrm{Aa}$ & $0.14 \mathrm{Bb}$ & $0.70 \mathrm{Aa}$ & $0.64 \mathrm{Aa}$ & $0.09 \mathrm{Aa}$ & $0.09 A a$ & $0.75 \mathrm{Aa}$ & $0.69 A a$ & $0.63 \mathrm{Aa}$ & $0.62 \mathrm{Ba}$ & $0.40 \mathrm{Aa}$ & $0.40 \mathrm{Ba}$ \\
\hline 凹 & IAC-RBca10 & $0.16 \mathrm{Aa}$ & $0.17 A a$ & $0.65 \mathrm{Aa}$ & $0.66 \mathrm{Aa}$ & $0.09 A a$ & 0.09Aa & $0.73 \mathrm{Aa}$ & $0.75 \mathrm{Aa}$ & $0.67 A a$ & $0.74 A a$ & $0.49 A b$ & $0.56 \mathrm{Aa}$ \\
\hline & IAC-BeCa-095 & $0.14 A b$ & $0.18 A a$ & $0.64 \mathrm{Ab}$ & $0.72 A a$ & $0.07 \mathrm{Bb}$ & $0.09 \mathrm{Aa}$ & $0.70 \mathrm{Aa}$ & $0.80 \mathrm{Aa}$ & $0.55 \mathrm{Ab}$ & $0.70 \mathrm{Aa}$ & $0.44 \mathrm{Aa}$ & $0.45 \mathrm{Ba}$ \\
\hline
\end{tabular}

${ }^{\star}$ Means with the same letter are not significantly different $(p<0.05)$ by the Scott-Knott's test. Capital letters compare bacterial treatments and lower case letters compare AMF inoculation. Bold mean refers to the best result for each nutrient.

Table 5. Shoot concentration $\left(\mathrm{g} \cdot \mathrm{kg}^{-1}\right)$, content $\left(\mathrm{g} \cdot\right.$ plant $\left.{ }^{-1}\right)$ and nutrient $\mathrm{UEI}\left(\mathrm{g}^{2} \cdot \mathrm{g}^{-1} \cdot\right.$ nutrient) of micronutrients in sugarcane seedlings inoculated with PGPB and mixture of AMF. (Experiment 3 ).

\begin{tabular}{|c|c|c|c|c|c|c|c|c|c|c|c|}
\hline & Nutrients & & & & & & & & & & \\
\hline & & & & & & & & & & & \\
\hline & & Without & With & Without & With & Without & With & Without & With & Without & With \\
\hline 듬 & Control & $65.70 \mathrm{Ba}$ & 53.63Aa & 4.87Aa & 5.27Aa & 149.37Aa & 127.13Bb & 49.40Aa & $52.40 \mathrm{Aa}$ & 26.27Aa & 20.77Bb \\
\hline$\frac{0}{2}$ & IAC-RBca10 & 82.47Aa & $53.43 \mathrm{Ab}$ & 4.87Aa & $4.93 \mathrm{Ba}$ & 148.37Aa & 141.77Aa & 49.47Ab & 57.77Aa & $26.80 \mathrm{Aa}$ & 25.00Aa \\
\hline ర) & IAC-BeCa-095 & $50.03 \mathrm{Ca}$ & 49.33Aa & 5.07Ab & 6.00Aa & $129.33 \mathrm{Bb}$ & 144.70Aa & $43.27 \mathrm{Bb}$ & 53.37Aa & 25.80Aa & 29.23Aa \\
\hline & Control & $174.00 \mathrm{Ba}$ & $126.66 \mathrm{Ab}$ & $12.66 \mathrm{Aa}$ & $12.33 \mathrm{Ba}$ & $394.66 \mathrm{Aa}$ & $300.00 \mathrm{Cb}$ & $130.33 \mathrm{Aa}$ & $123.66 \mathrm{Ba}$ & 69.33Aa & $49.33 \mathrm{Cb}$ \\
\hline$\stackrel{\oplus}{\check{L}}$ & IAC-RBca10 & 213.33Aa & $147.33 \mathrm{Ab}$ & $12.33 \mathrm{Aa}$ & $13.66 \mathrm{Ba}$ & 384.33Aa & 391.00Ba & $128.33 \mathrm{Ab}$ & $159.66 \mathrm{Aa}$ & 69.00Aa & $69.00 \mathrm{Ba}$ \\
\hline & IAC-BeCa-095 & $118.33 \mathrm{Ca}$ & 147.00Aa & $12.00 \mathrm{Ab}$ & $18.00 \mathrm{Aa}$ & 306.00Bb & 431.33Aa & $102.00 \mathrm{Bb}$ & $159.00 \mathrm{Aa}$ & $61.00 \mathrm{Ab}$ & 87.00Aa \\
\hline & Control & $0.04 \mathrm{Aa}$ & $0.04 \mathrm{Aa}$ & $0.55 \mathrm{Aa}$ & $0.45 \mathrm{Ab}$ & $0.02 \mathrm{Aa}$ & $0.02 \mathrm{Aa}$ & $0.05 \mathrm{Aa}$ & $0.04 \mathrm{Bb}$ & $0.10 \mathrm{Aa}$ & $0.11 A a$ \\
\hline Ш & IAC-RBca10 & $0.03 \mathrm{Ab}$ & $0.05 \mathrm{Aa}$ & $0.53 \mathrm{Aa}$ & $0.56 \mathrm{Aa}$ & $0.02 \mathrm{Aa}$ & $0.02 \mathrm{Aa}$ & $0.05 \mathrm{Aa}$ & $0.05 \mathrm{Ba}$ & $0.10 \mathrm{Aa}$ & $0.11 \mathrm{Aa}$ \\
\hline & IAC-BeCa-095 & $0.05 A b$ & $0.06 \mathrm{Aa}$ & $0.47 A a$ & $0.50 \mathrm{Aa}$ & $0.02 \mathrm{Aa}$ & $0.02 \mathrm{Aa}$ & $0.05 \mathrm{Aa}$ & $0.06 \mathrm{Aa}$ & $0.09 A a$ & $0.10 \mathrm{Aa}$ \\
\hline
\end{tabular}

${ }^{\star}$ Means with the same letter are not significantly different $(p<0.05)$ by the Scott-Knott's test. Capital letters compare bacterial treatments and lower case letters compare AMF inoculation. Bold mean refers to the best result for each nutrient.

Regarding the nutrient concentrations, coinoculation with IAC-BeCa-095 (K. radicincitans) and AMF increased the Ca concentration (Table 4). The coinoculation of these microorganisms also resulted in higher nutrient contents and UEI values (Table 4). According to Jacoby (2017), these results can be associated with the beneficial characteristics of the bacterial strain, such as nifH amplification, suggesting that BNF can be associated with plant growth promotion and the mineralization and absorption of macronutrients (N, P and S). The nutritional status of plants is often associated with an increase in root growth caused by bacteria (Witzel et al. 2017), which occurred in the present experiment. These beneficial microorganisms, commonly referred to as biofertilizers, which include bacteria and fungi, increase the plant ability to absorb nutrients; therefore, they are used as a complement to mineral fertilization, consequently resulting in shoot and root biomass increasing (Calvo et al. 2014). The plant roots showed lower growth rates with AMF and IAC-RBca10 inoculation (Fig. 1), most likely due to the high fertility level of the substrate. This high fertility level may have inhibited the action of both beneficial microorganisms, fungal and bacterial strains. Besides 
this, substrates fertilized with thermophosphate and ammonium sulfate, as done in the present study, promote better sugarcane seedling development (Gazola et al. 2017).

\section{OVERALL COMMENTS}

In general, all bacterial strains tested resulted in an increase in shoot biomass, especially IAC-RBca5 and IAC-BeCa-088 (Fig. 1), without AMF mixture inoculation. In the treatments with AMF, the strains IAC-RBca10 and IAC-BeCa-088 also increased shoot biomass, and the IAC-BeCa-095 strain caused the greatest increase in root biomass. (Figs. 1 and 3). The improvement in root biomass triggered by beneficial microorganisms is highly desirable for PSS sugarcane because the shoots of the seedlings are pruned during the acclimation phase of seedling production and before transplantation to the field. Therefore, the more robust root system may favor the plant and ensure greater survival and adaptation after transplantation to the field (Xavier at al. 2016). The use of microorganisms as agents for both biological control and plant growth promotion is an alternative to conventional agricultural techniques (Müller et al. 2016). The sugarcane PSS system is considered to be a new technique for the plant production and many aspects of this production process need to be better studied, mainly regarding fertilization, because there are differences in nutrient requirements during this initial period of seedling development. Therefore, the microorganisms, both bacteria and AMF, that were tested in the current research showed variable results depending on the bacterial strain and fertilization management. In experiments 1 and 2 , the use of a substrate with partial fertilization and without fertilization, respectively, resulted in an increase in shoot biomass, mainly with the inoculation of strains IAC-BeCa-088 (B. caribensis) and IAC-RBca5 (Pseudomonas sp.) without the inoculation of AMF. In experiment 3, with the use of substrate with recommended fertilization, coinoculation with strain IAC-BeCa-095 (K. radicincitans) and AMF increased both the shoot and root mass, showing a synergistic effect between both microorganisms (Figs. 1 and 3).

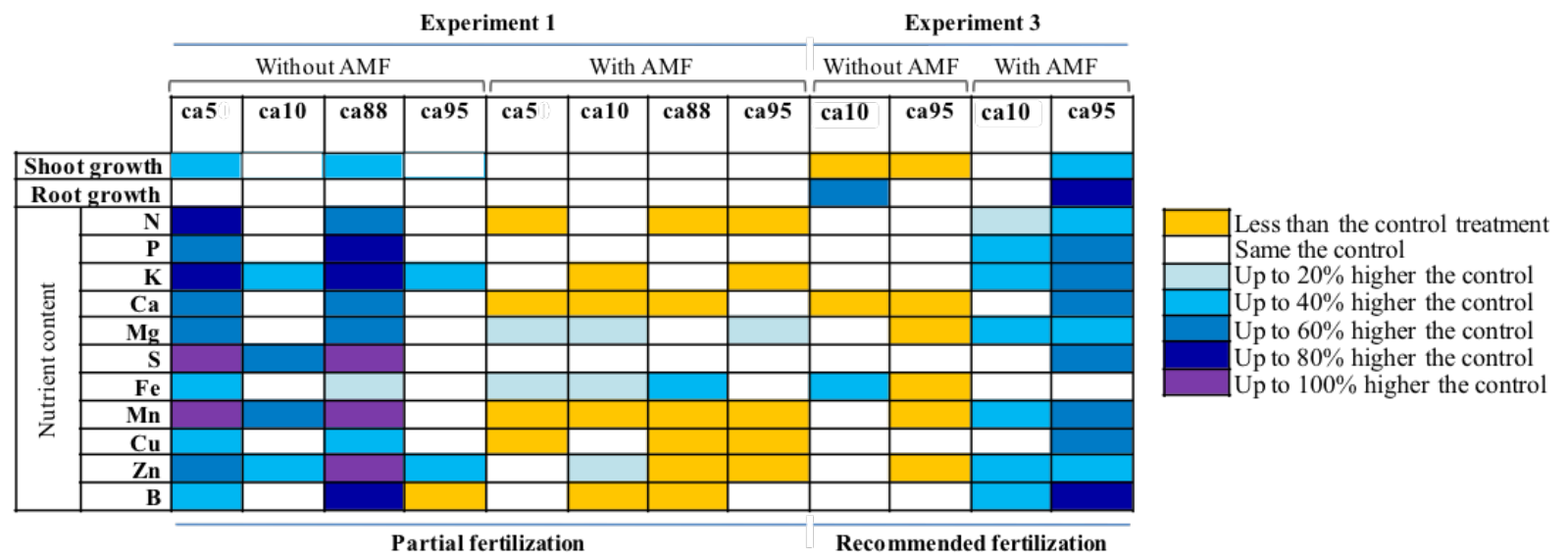

Figure 3. Effects triggered by bacteria strains (IAC-RBca5, IAC-RBca10, IAC/Beca-088 and IAC/BEca-095) on sugarcane seedlings development (without or with arbuscular mycorrhizal fungi - AMF) regarding plant shoot and root growth and nutrient content, in experiment 1 and 3 (with partial and recommended fertilization, respectively).

Another important point is that the bacterial strains were tested in two challenging conditions: in all three experiments, the seedlings were treated with fungicides and the substrate received high doses of fertilizers (both standard procedures in PSS production system). The beneficial effect triggered by beneficial microorganisms is dependent on the soil/substrate fertility, and this benefit is more evident when the environment has at least half of the desirable nutrients available (Abbott et al. 2018). The main beneficial effect triggered by the bacterial inoculants on plant development occurred without inoculation of AMF mixture, in experiment 1, with partial fertilization of the substrate (Fig. 3). This beneficial effect was observed both in the biomass improvement (shoot and root growth) and in plant shoot concentration and content nutrients. The K, S, Ca and Mn concentrations, mainly in plants inoculated with strains IAC-RBca5 and IAC-BeCa-088 without AMF, are in accordance 
with the sugarcane nutritional levels (Raij and Cantarella 1996). Besides that, this experimental design simulated the PGPB and AMF effects under different scenarios of fertilization in an attempt to adequately inoculate microorganisms under similar conditions to those observed in PSS production. Appropriate management practices are important for production aspects that would allow microorganism inoculation to be more feasible for sugarcane seedling producers.

\section{CONCLUSION}

Bacteria strains with plant growth-promoting traits are able to improve sugarcane PSS development. This study is the first to show the synergistic effect of $K$. radicincitans (IAC-BeCa-095) or Bacillus sp. (IAC-RBca10) with AMF inoculum on sugarcane PSS production. These bacteria and also B. caribensis (IAC-BeCa-088) and Pseudomonas sp. (IAC-RBca5) benefit plant development and especially the plant nutrition, without AMF inoculum. This study contains valuable information on the use of beneficial microorganisms, such as rhizosphere and endophytic bacteria and AMF, as an excellent alternative to conventional agricultural techniques to optimize sugarcane seedling production.

\section{AUTHORS' CONTRIBUTION}

Conceptualization: Silveira A. P. D. and Cipriano M. A. P.; Methodology: Rossetto L., Pierangeli G. M. F., Xavier M. A. and Cipriano M. A. P.; Investigation: Rossetto L. and Pierangeli G. M. F.; Writing - Original Draft: Rossetto L. and Pierangeli G. M. F.; Writing - Review and Editing: Silveira A. P. D., Cipriano M. A. P. and Kuramae, E. E.; Funding Acquisition: Silveira, A. P. D. and Kuramae E. E.; Supervision: Silveira A. P. D. and Cipriano M. A. P.

\section{DATA AVAILABILITY STATEMENT}

All dataset were generated or analyzed in the current study.

\section{FUNDING}

Coordenação de Aperfeiçoamento de Pessoal de Nível Superior

[https://doi.org/10.13039/501100002322]

Finance Code 001

Conselho Nacional de Desenvolvimento Científico e Tecnológico

[https://doi.org/10.13039/501100003593]

Grant No. 456420/2013-4

Fundação de Amparo à Pesquisa do Estado de São Paulo

[https://doi.org/10.13039/501100001807]

Grant No. 2008/56147-1

The Netherlands Organization for Scientific Research

[https://doi.org/10.13039/501100003246]

Grant No. 729.004.016

The Netherlands Institute of Ecology

Grant No. 7076 


\section{ACKNOWLEDGMENTS}

The authors thank Rosana Gonçalves Gierts for laboratory assistance.

\section{REFERENCES}

Abbott, L. K., Macdonald, L. M., Wong, M. T. F., Webb, M. J., Jenkins, S. N. and Farrell, M. (2018). Potential roles of biological amendments for profitable grain production - A review. Agriculture, Ecosystems and Environment, 256, 34-50.

Abdel-Fattah, G. M., Asrar, A. A., Al-Amri, S. M. and Abdel-Salam, E. M. (2014). Influence of arbuscular mycorrhizal and phosphorus fertilization on the gas exchange, growth and phosphatase activity of soybean (Glycine max L.) plants. Photosynthetica, 52, $581-588$. https://doi.org/10.1007/s11099-014-0067-0

Andrade, S. A. L., Gratão. P. L., Azevedo R. A.; Silveira A. P. D., Schiavinato, M. A. and Mazzafera, P. (2010). Biochemical and physiological changes in jack bean under mycorrhizal symbiosis growing in soil with increasing Cu concentrations. Environmental and Experimental Botany, 68, 198-207.

Badr, M. A. (2006). Efficiency of K-feldspar Combined with Organic Materials and Silicate Dissolving Bacteria on Tomato Yield. Journal of Applied Science Research, 2, 1191-1198.

Bakker, A. W. and Schippers, B. (1987). Microbial cyanide production in the rhizosphere in relation to potato yield reduction and Pseudomonads SPP.-mediated plant growth-stimulation. Soil Biology and Biochemistry, 19, 451-457. https://doi. org/10.1016/0038-0717(87)90037-X

Bataglia, O. C., Furlani, A. M. C., Teixeira, J. P. F., Furlani, P. R. and Gallo, J. R. (1983). Métodos de análise química de plantas [IAC Boletim Técnico 78]. Campinas: Instituto Agronômico de Campinas.

Bhardwaj, D., Ansari, M. W., Sahoo, R. K. and Tuteja, N. (2014). Biofertilizers function as key player in sustainable agriculture by improving soil fertility, plant tolerance and crop productivity. Microbial Cell Factories, 13, 66. https://doi.org/10.1186/1475-2859-13-66

Bhromsiri, C. and Bhromsiri, A. (2010). The effects of plant growth-promoting rhizobacteria and arbuscular mycorrhizal fungi on the growth, development and nutrient uptake of different vetiver ecotypes. Thai Journal of Agricultural Science, 43, 239-249.

Bona, E., Todeschini, V., Cantamessa, S., Cesaro, P., Copetta, A., Lingua, G., Gamalero, E., Berta, G. and Massa, N. (2018). Combined bacterial and mycorrhizal inocula improve tomato quality ant reduced fertilization. Scientia Horticulturae, 234, 160-165. https://doi. org/10.1016/j.scienta.2018.02.026

Bric, J. M., Bostock, R. M. and Silverston, S. E. (1991). Rapid in situ assay for indoleacetic acid production by bacteria immobilized on a nitrocellulose membrane. Applied and Environmental Microbiology, 57, 535-538. https://doi.org/10.1128/AEM.57.2.535-538.1991

Calvo, P., Nelson, L. and Kloepper, J. W. (2014). Agricultural uses of plant biostimulants. Plant and Soil, 383, 3-41. https://doi.org/10.1007/ s11104-014-2131-8

Cipriano, M. A. P., Freitas-lório, R. P., Dimitrov, M. R., Andrade, S.A.L., Kuramae, E.E., Silveira, A. P. D. (2021). Plant-growth endophytic bacteria improve nutrient use efficiency and modulate foliar N-metabolites in sugarcane seedling. Microorganisms 2021, 9, 479. https:// doi.org/10.3390/microorganisms9030479

Cipriano, M. A. P., Lupatini, M., Lopes-Santos, L., Silva, M. J., Roesch, L. F. W., Destéfano, S. A. L., Freitas, S. S. and Kuramae, E. E. (2016). Lettuce and rhizosphere microbiome responses to growth promoting Pseudomonas species under field conditions. FEMS Microbiology Ecology, 92, fiw197. https://doi.org/10.1093/femsec/fiw197 
Cormier, F., Foulkes, J., Hirel, B., Gouache, D., Moënne-Loccoz, Y., Le Gouis, J. (2016). Breeding for increased nitrogen-use efficiency: a review for wheat (T. aestivum L.). Plant Breeding, 135, 255-278. https://doi.org/10.1111/pbr.12371

Döbereiner, J., Baldani, V. L. D. and Baldani, J. I. (1995). Como isolar e identificar bactérias diazotróficas de plantas não-leguminosas. Brasília: Embrapa-SPI.

Ferreira, D. F. (2008). Sisvar: um programa para análises e ensino de estatística. Revista Cientia Symposium, 6, 36-41.

Finkel, O. M., Castrillo, G., Paredes, S. H., Gonzáles, I.S. and Dangl, J. L. (2017). Understanding and exploiting plant beneficial microbes. Current Opinion in Plant Biology, 38, 155-163. https://doi.org/10.1016/j.pbi.2017.04.018

Fusconi, A. (2014). Regulation of root morphogenesis in arbuscular mycorrhizae: what role do fungal exudates, phosphate, sugars and hormones play in lateral root formation? Annals of Botany, 113, 19-33. https://doi.org/10.1093/aob/mct258

Gazola, T., Cipola Filho, M. L. and Franco Júnior, N. C. (2017). Avaliação de mudas pré-brotadas de cana-de-açúcar provenientes de substratos submetidos a adubação química e orgânica. Científica, 45, 300-306. https://doi.org/10.15361/1984-5529.2017v45n3p300-306

Giovannetti, M. and Mosse, B. (1980). An Evaluation of Techniques for Measuring Vesicular Arbuscular Mycorrhizal Infection in Roots. New Phytologist, 84, 489-500. https://doi.org/10.1111/j.1469-8137.1980.tb04556.x

González, A. M., Victoria, D. E. and Merino, F. C. G. (2015). Efficiency of Plant Growth Promoting Rhizobacteria (PGPR) in Sugarcane. Terra Latinoamericana, 33, 321-330.

Guo, Y.-J, Ni, Y. and Huang, J.-H. (2010). Effects of rhizobium, arbuscular mycorrhiza and lime on nodulation, growth and nutrient uptake of lucerne in acid purplish soil in China. Tropical Grasslands, 44, 109-114.

Jacoby, R., Peukert, M., Succurro, A., Koprivova, A. and Kopriva, S. (2017). The Role of Soil Microorganisms in Plant Mineral NutritionCurrent Knowledge and Future Directions. Frontiers in Plant Science, 8, 1617. https://doi.org/10.3389/fpls.2017.01617

Katznelson, H. and Bose, B. (1959). Metabolic Activity and Phosphate Dissolving Capability of Bacterial Isolates from Wheat Roots, Rhizosphere, and Non-Rhizosphere Soil. Canadian Journal of Microbiology, 5, 79-85. https://doi.org/10.1139/m59-010

Kleingesinds, C. K., Ferrara, F. I. S., Floh E. I. S., Aidar, M. P. M and Barbosa, H. R. (2018). Sugarcane growth promotion by Kosakonia sp. ICB117 an endophytic and diazotrophic bacterium. African Journal of Microbiology Research, 12, 105-114. https://doi.org/10.5897/ AJMR2017.8738

Landell, M. G. A., Campana, M. P., Figueiredo, P., Xavier, M. A., Anjos, I. A., Dinardo-Miranda, L. L., Scarpari, M. S., Garcia, J. C., Bidóia, M. A. P., Silva, D. N., Mendonça, J. R., Kanthack, R. A. D., Campos, M. F., Brancalião, S. R., Petri, R. H. and Miguel, P. E. M. (2012). Sistema de multiplicação de cana-de-açúcar com uso de mudas pré-brotadas (MPB), oriundas de gemas individualizadas [Documentos IAC 109]. Campinas: Instituto Agronômico de Campinas.

Lata, R., Chowdhury S., Gond, S. K. and White Junior, J. F. (2018). Induction of abiotic stress tolerance in plants by endophytic microbes. Letters in Applied Microbiology, 66, 268-276. https://doi.org/10.1111/lam.12855

Loján, P., Senés-Gierrero, C., Suárez, J. P., Kromann, P., Schüßler, A. and Declerck, S. (2017). Potato field-inoculation in Ecuador with Rhizophagus irregularis: no impact on growth performance and associated arbuscular mycorrhizal fungal communities. $73,45-56$. https://doi.org/10.1007/s13199-016-0471-2

Marcos, F. C. C., lório, R. P. F., Silveira, A. P. D., Ribeiro, R. V., Machado, E. C. and Lagôa, A. M. M. A. (2016). Endophytic bacteria affect sugarcane physiology without changing plant growth. Bragantia, 75, 1-9. https://doi.org/10.1590/1678-4499.256

Meena, V. S., Meena, S. K., Verma, J. P., Kumar, A., Aeron, A., Mishra, P. K., Bisht, J. K., Pattanayak, A., Naveed, M. and Dotaniya, M. L. (2017). Plant beneficial rhizospheric microorganism (PBRM) strategies to improve nutrients use efficiency: A review. Ecological Engineering, 107, 8-32. https://doi.org/10.1016/j.ecoleng.2017.06.058 
Mohan, J. E., Cowden, C. C., Bass, P., Dawadi, A., Frankson, P. T., Helmick, K., Hughes, E., Khan, S., Lang, A., Machmuller, M., Taylor, M. and Witt, C. A. (2014). Mycorrhizal fungi mediation of terrestrial ecosystem responses to global change: mini-review. Fungal Ecology, 10, 3-19. https://doi.org/10.1016/j.funeco.2014.01.005

Müller, C. A., Obermeier, M. M., Berg, G. (2016). Bioprospecting plant-associated microbiomes. Journal of Biotechnology, 235, 171-180. https://doi.org/10.1016/j.jbiotec.2016.03.033

Nadeem, S. M., Ahmad, M., Zahir, Z. A., Javaid, A., Ashraf, M. (2014). The role of mycorrhizae and plant growth promoting rhizobacteria (PGPR) in improving crop productivity under stressful environments. Biotechnology Advances, 32, 429-448. https://doi.org/10.1016/j. biotechadv.2013.12.005

Nunes, C. E. P., Stancatto, G. and Silveira A. P. D. (2014). Anthurium growth responses to phosphate fertilization and inoculation with an arbuscular mycorrhizae fungus. Journal of Horticultural Science and Biotechnology, 89, 261-267. https://doi.org/10.1080/14620316 .2014 .11513077

Olanrewaju, O. S., Glick, B. R., Babalola, O. O. (2017). Mechanisms of action of plant growth promoting bacteria. World Journal of Microbiology and Biotechnology, 33, 197. https://doi.org/10.1007/s11274-017-2364-9

Phillips, J. M. and Hayman, D. S. (1970). Improved procedures for clearing roots and staining parasitic and vesicular-arbuscular mycorrhizal fungi for rapid assessment of infection. Transactions of the British Mycological Society, 55, 158-161.

Raij, B. and Cantarella, H. (1996). Outras culturas industriais. In B. Raij, H. Cantarella, J. A. Quaggio, A. M. C. Furlani (Eds.), Recomendações de adubação e calagem para o Estado de São Paulo (p. 233-236). Campinas: Instituto Agronômico e Fundação IAC.

Rampazzo, P. E., Marcos, F. C. C., Cipriano, M. A. P., Marchiori, P. E. R. Freitas, S. S., Machado, E. C. Nascimento, L. C., Brocchi, M. and Ribeiro, R. V. (2018). Rhizobacteria improve sugarcane growth and photosynthesis under well watered conditions. Annals of Applied Biology, 172, 309-320. https://doi.org/10.1111/aab.12421

Reis, C. H., Figueira, A. R. and Oliveira, E. (1994). Tratamento térmico, fungicida e de micorrizas vesículo-arbusculares no desenvolvimento de mudas de cana-de-açúcar (Saccharum spp). Fitopatologia Brasileira, 19, 495-498.

Rodriguez, A. and Sanders, I. R. (2015). The role of community and population ecology in applying mycorrhizal fungi for improved food security. The ISME Journal, 9, 1053-1061. https://doi.org/10.1038/ismej.2014.207

Santos, R. M., Kandasamy, S. and Rigobelo, E. C. (2018). Sugarcane growth and nutrition levels are differentially affected by the application of PGPR and cane waste. MicrobiologyOpen, 7, e00617. https://doi.org/10.1002/mbo3.617

Santos, S. G., Ribeiro, F. S., Alves, G. C., Santos, L. A. and Reis, V. M. (2020). Inoculation with five diazotrophs alters nitrogen metabolism during the initial growth of sugarcane varieties with contrasting responses to added nitrogen. Plant and Soil, 451, 25-44. https://doi. org/10.1007/s11104-019-04101-1

Schultz, N., Pereira, W., Silva, P. A., Baldani, J. I., Boddey, R. M., Alves, B. J. R., Urquiaga, S. and Reis, V. M. (2017). Yield of sugarcane varieties and their sugar quality grown in different soil types and inoculated with a diazotrophic bacteria consortium. Plant Production Science, 20, 366-374. https://doi.org/10.1080/1343943X.2017.1374869

Siddiqi, M. Y. and Glass, A. D. M. (1981). Utilization index: A modified approach to the estimation and comparison of nutrient utilization efficiency in plants. Journal of Plant Nutrition, 4, 289-302. https://doi.org/10.1080/01904168109362919

Silveira, A. P. D., Sala, V. M. R., Cardoso, E. J. B. N., Labanca, E. G. and Cipriano, M. A. P. (2016). Nitrogen metabolism and growth of wheat plant under diazotrophic endophytic bacteria inoculation. Applied Soil Ecology, 107,313-319. https://doi.org/10.1016/j.apsoil.2016.07.005

Silveira, A. P. D.; lório, R. P. F.; Marcos, F. C. C. Fernandes, A. O., Souza, S. A. C. D., Kuramae, E. E. and Cipriano, M. A. P. (2018). Exploitation of new endophytic bacteria and their ability to promote sugarcane growth and nitrogen nutrition. Antonie van Leeuwenhoek, 112, 283295. http:/doi.org/10.1007/s10482-018-1157-y 
Singh, R., Soni, S. K. and Kalra, A. (2013). Synergy between Glomus fasciculatum and a beneficial Pseudomonas in reducing root diseases and improving yield and forskolin content in Coleus forskohlii Briq. under organic field conditions. Mycorrhiza, $23,35-44$. https://doi.org/10.1007/s00572-012-0447-x

Souza, R. S. C., Okura, V. K., Armanhi, J. S. L., Jorrín, N., Lozano, N., Silva, M. J., González-Guerrero, M., Araújo, L. M., Verza, N. C., Bagheri, H. C., Imperial, J. and Arruda, P. (2016). Unlocking the bacterial and fungal communities assemblages of sugarcane microbiome. Scientific Reports, 6, 28774. https://doi.org/10.1038/srep28774

Tahat, M. M. and Sijam, K. (2012). Arbuscular mycorrhizal fungi and plant root exudates bio-communications in the rhizosphere. African Journal of Microbiology Research, 6, 7295-7301.

Tarraf, W., Ruta, C., Tagarelli, A., De Cillis, F. and De Mastro, G. (2017). Influence of arbuscular mycorrhizae on plant growth, essential oil production and phosphorus uptake of Salvia officinalis L. Industrial Crops and Products, 102, 144-153. https://doi.org/10.1016/j. indcrop.2017.03.010

Todeschini, V., AitLahmidi, N., Mazzucco, E., Marsano, F., Gosetti, F., Robotti, E., Bona, E., Massa, N., Bonneau, L., Marengo, E., Wipf, D., Berta, G. and Lingua, G. (2018). Impact of beneficial microorganisms on strawberry growth, fruit production, nutritional quality, and volatilome. Frontiers in Plant Science, 9, 1611. https://doi.org/10.3389/fpls.2018.01611

Ueda, T., Suga, Y., Yahiro, N. and Matsuguchi, T. (1995). Remarkable $\mathrm{N}_{2}$-fixing bacterial diversity detected in rice roots by molecular evolutionary analysis of nifH gene sequences. Journal of Bacteriology, 177, 1414-1417. https://doi.org/10.1128/JB.177.5.1414-1417.1995

Venturi, V. and Keel, C., (2016). Signaling in the Rhizosphere. Trends in Plant Science, 21, 187-198. https://doi.org/10.1016/j.tplants.2016.01.005

Witzel, K., Üstün, S., Schreiner, M., Grosch, R., Börnke, F. and Ruppel, S. (2017). A proteomic approach suggests unbalanced proteasome functioning induced by the growth-promoting bacterium Kosakonia radicincitans in Arabidopsis. Frontiers in Plant Science, 8, 661.

Wu, S. C., Cao, Z. H., Li, Z. G., Cheung, K. C. and Wong, M. H. (2005). Effects of biofertilizer containing N-fixer, P and K solubilizers and AM fungi on maize growth: a greenhouse trial. Geoderma, 125, 155-166. https://doi.org/10.1016/j.geoderma.2004.07.003

Xavier, M. A., Landell, M. G. A., Campana, M. P. and Rossetto, R. (2016). Sugarcane multiplication system with the use of pre-sprouting seedlings (MPB). Sugar Journal, 8-11. [Accessed May, 5, 2020]. Available at: https://www.sugarjournal.com/ 